\title{
Okul Yöneticileri Kendi Mesleki Gelişim Etkinliklerini Nasıl Algilıyorlar?'
}

\author{
Gamze KASALAK $^{*}$
}

\begin{abstract}
Öz: Bu araştırmanın amacı, okul yöneticilerinin kendi mesleki gelişim etkinliklerine yönelik algılarını belirlemektir. Genel tarama modelinde tasarlanan araştırmanın çalışma grubunda, Antalya ili devlet ilkokulu, ortaokulu ve liselerinde görev yapan ve "Okul Yönetimi Semineri" ne katılan basit seçkisiz örnekleme yöntemi ve gönüllük esasına göre belirlenen 100 okul yöneticisi bulunmaktadır. Araştırma verileri, Mesleki Gelişim Etkinliği anketi kullanılarak toplanmıştır. Araştırma bulguları, okul yöneticilerinin resmi mesleki gelişim etkinliklerinden en fazla kurs ve çalıştay türü etkinliklere katıldıklarını ancak en etkili algılanan mesleki gelişim etkinliklerinin meslektaşlara rehberlik etme, gözlemleme ve yetiştirme olduğunu göstermektedir. Okul yöneticilerinin ihtiyaç duydukları mesleki gelişim alanları arasında en fazla oranda okul (iş) sağlığı ve güvenliği, etkili iletişim becerileri, eğitimde bilgi teknolojileri kullanma becerileri ve öğrenci disiplin ve davranış sorunları konuları yer almaktadır. Okul yöneticilerimesleki gelişim etkinliklerine daha fazla oranda katılmak istediklerini ve katıldıkları mesleki gelişim etkinlikleri için ek ödeme yapılmadığını belirtmektedirler.
\end{abstract}

Anahtar Sözcükler: Mesleki Gelişim, Mesleki Gelişim Etkinlikleri, Okul Yöneticileri

\section{How Do School Administrators Perceive Their Professional Development Activities?}

\begin{abstract}
The present study aims to determine school administrator perceptions of their professional development activities. The study was designed using a general survey model. The participants, who were selected using a random sampling method and on a volunteer basis, included 100 school administrators who worked in the state primary, secondary, and high schools in the province of Antalya and who participated in the "School Administration Seminar." Research data were collected via a Professional Development Activities Questionnaire. The study findings indicated that school administrators participated most in official professional development activities like courses and workshops, and the professional development activity that was perceived as the most effective was guiding, observing and training one's colleagues. The professional development areas most needed by school administrators included school (occupational) health and safety, effective communication skills, ability to use information technology in education, and student discipline and behavior problems. In addition, school administrators stated that they wanted to participate in professional development activities more and that they did not receive any additional payment for the professional development activities in which they participated.
\end{abstract}

Keywords: Professional Development, Professional Development Activities, School Administrators 
Mesleki gelişim, bireylerin mesleğine başlamadan önceki hizmet öncesinden emekliliğine kadar geçen süreçleri kapsayan ve yaşam boyu devam eden formal ve informal öğrenmelerin toplamıdır (Fullan ve Steigelbauer, 1991; Kasar ve Clark, 2000). Bireylerin kendilerini mesleklerinin gerektirdiği teknik, yasal, kavramsal ve sosyal değişim alanlarında güncel tutukları uygulamalar (Murphy ve Calway, 2008) ve bireylerin becerilerini, bilgilerini, uzmanlıklarını ve diğer niteliklerini geliştiren etkinlikler (Milli Eğitim Bakanlığ 1 [MEB], 2010) de mesleki gelişim olarak tanımlanmaktadır. Watts ve Hammons'a (2002) göre, mesleki gelişim bireyin belirli bir alanda; bilgi ve beceri bakımından donanımlı olmak, bireysel olarak yenileşmek ve gelişmek için gerçekleştirdiği etkinliklerdir. Eğitim kurumlarındaki mesleki gelişim ise, eğitim personeline sunulan ve eğitim personelinin mesleki bilgi, beceri ve tutumlarını geliştirmeyi amaçlayan eğitsel süreç ve etkinliklerin bütünüdür (Guskey, 2002; 2009; Şanl, 2016). Mesleki gelişim etkinlikleri, öğretmen ve eğitim kurumu yöneticilerinin niteliklerini artırmaları ve kendi güç ve yeteneklerini kullanabilmeleri açısından önemlidir (Seferoğlu, 2004). Alanyazında mesleki gelişim etkinliklerinin öğretmen ve yöneticiler açısından faydaları şu şekilde belirtilmektedir (Harris, 1989): Bireylerin bilimsel, eğitsel ve bireysel yeterliliklerini artırarak mesleki gelişimlerini özendirmek, bireyleri mesleki açıdan tatmin etmek, bireylerin performanslarını geliştirmek, genel ve özel öğretimsel amaçları geliştirmek, öğretim kaynaklarını geliştirmek ve öğretme iklimini iyileştirmek. Tüm bu görüşler doğrultusunda, okul yöneticilerinin hizmet içinde yetiştirilmesi ve mesleki gelişimlerini sağlamanın yönetimin işlevlerini yerine getirmede ve bilimsel, teknolojik, ekonomik ve toplumsal değişimlere uyum sağlamadaönemli bir ihtiyaç olduğundan söz edilebilir (Ingvarson, Meiers ve Beavis, 2005; Seferoğlu, 2004; Sezgin-Nartgün, 2006; Şahin, 1999; Taymaz, 1997).

Okul yöneticilerinin eğitim kurumlarındaki tüm kaynakları etkili bir şekilde kullanarak okullarını belirli eğitsel amaçlara ulaştırmak (Bursalığlu, 2015); personel, öğrenci, öğretim ve eğitim hizmetleri ile okul işletmesini sağlamak (Taymaz, 1997) gibi görevleri bulunmaktadır. Ayrıca, öğretmenlerin mesleki gelişimlerini iyileştirmek, öğretmenlerin nitelikli eğitim verebilmelerini sağlamak ve okullarını yenileştirmek, geliştirmek ve değişime ayak uydurmasını sağlamak (Polat, Uğurlu ve Aksu, 2018) gibi sorumlulukları da vardır. Bu nedenle, okul yöneticilerinin görev ve sorumluluklarını yerine getirebilmeleri için yetiştirilmelerine, profesyonelce yenilenmelerine ve kendilerini geliştirmeye ihtiyaçları olabilir. Okul yöneticilerinin bilimsel, teknolojik, ekonomik ve sosyal değişimlere uyum sağlamaları onların hem kişisel çabaları hem de planlı ve programlı bir şekilde hazırlanan mesleki gelişim etkinliklerine katılmaları ile gerçekleşebilir. Okul yöneticilerine yönelik mesleki gelişim etkinlikleri resmi açıdan MEB'e bağlı Personel Genel Müdürlüğü [PGM] bünyesinde yer alan Eğitim Daire Başkanlığı tarafından planlanmakta ve yürütülmektedir (MEB, 2019b). MEB Öğretmen Yetiştirme ve Geliştirme Genel Müdürlüğü Mesleki Gelişimi Destekleme ve İzleme Dairesi Başkanlığında ve Hizmetiçi Eğitim Yönetmeliği'nde (1994) de okul yöneticilerinin "hayat boyu öğrenme" ilkeleri kapsamında mesleki ve kişisel gelişmelerinin sağlanması, gelişimlere intibak etmeleri, verimliliklerinin arttırılması ve üst görevlere hazırlanmaları amacıyla hizmetiçi eğitim etkinliklerine katılabilecekleri belirtilmektedir (MEB, 2019a). Mesleki gelişim etkinliklerin eğitim personelinin iş doyumu, okul kültürü algıları, örgüte güven, verimlilik ve üretkenlikleri üzerinde olumlu yönde etkisinin olması (Chen, Chang ve Yeh, 2004; Erakkuş, 2004; Kızılkaya, 2012; Kocatürk, 2016) mesleki gelişim etkinliklerini daha da önemli hale getirmektedir. Ancak mesleki gelişim etkinliklerinin gerekliliğine inanılmasına rağmen etkililik düzeyi yeterli görülmemektedir (Aytaç, 2000; Doğan, 2009; Kahyaoğlu, 2019). Mesleki gelişimin etkili olmamasının nedenleri okul yöneticilerinin mesleki gelişim ihtiyaçlarının bakanlık merkezli belirlenmesi, katıldıkları eğitimler için genellikle ödeme yapılmaması ve bireysel çabaları ile eğitim masraflarını karşılamaları, eğitimi sunan uzmanların niteliksel ve niceliksel açıdan okul yöneticilerinin beklentilerini karşılamada yetersiz olmaları ve uygun bir zaman diliminde eğitimlerin sunulmamasıdır (Akkaya, 2010; Baz, 2010; Budak ve Demirel, 2003; Polat ve diğerleri, 2018; Uçar ve İpek, 2006; Urlunç, 2007).

Uluslararası alanyazında mesleki gelişim olarak adlandırılan etkinlikler ulusal alanyazında yaygın bir şekilde "çalışanlara mesleki bilgi ve becerilerini geliştirmeleri için çalıştıkları süre içinde verilen eğitim, işbaşında eğitim" (Türk Dil Kurumu [TDK], 2019) olarak tanımlanan hizmet içi eğitim terimi yerine kullanılmaktadır (Baykan, Güngen ve Ünal, 1987; Ersoy, 1996; Pakkan, 1995). Eğitim alanında hizmet içi eğitim, öğretmen, yönetici, denetmen ve diğer eğitim personelleri için mesleki gelişim etkinliklerinden biridir (Kayıkçı, Altun ve Altun, 2018). Mesleki gelişim konusunda gerçekleşen araştırmalar incelendiğinde başarılı 
bir personel geliştirme programında planlama, uygulama ve değerlendirme süreçlerinin yer alması gerektiği vurgulanmaktadır. Bunun için öğretme ve öğrenmeye odaklanılmalı, mesleki gelişim etkinlikleri okul gelişim hedeflerine uygun hazırlanmalı, zaman ve kaynak sağlamada yönetim tarafından destek sağlanmalı, etkin öğrenme ortamı gerçekleşmeli ve veriye dayalı program değerlendirmesi yapılmalıdır (Cormas ve Barufaldi, 2011; Gordon, 2004; Guskey, 2003). Lashway'a (2003) göre deneyimsiz okul liderleri ders kitaplarından anladıkları liderliği gerçek yaşamda pratiğe dökmeye kalkıştıklarında oldukça strese girmektedirler. Dolayısıyla okul yöneticileri yeni liderlik pozisyonunun zorlu yıllarında kendilerine destek olacak, meslekî işbirliklerini ve ilişkilerini geliştirecek bireylerin varlığına ihtiyaç duymaktadırlar. Mentorluk ve/veya koçluk hizmetleriyle okul yöneticilerinin mesleki gelişimlerine katkı sağlanabilir. Okul yöneticilerinin mesleki gelişimlerine bireyin kendisi tarafından aldığı eğitimler ve çalıştığı kurumun sağladığı ya da yönlendirdiği eğitimler de katkıda bulunabilir. Böylece okul yöneticileri, öğrenen okullara rehberlik etmek, okullarının vizyonunu geliştirmek, öğretim lideri olarak hizmet vermek, okulu yönetebilmek ve toplumsal işbirliğinde bulunabilmek, yeni bilgi ve beceriler kazanmak, öğretmenlerin problem çözme becerilerini artırabilmek konularında kazanımlar elde edeceklerdir (Nasreen ve Odhiambo, 2018; Özus, 2005). Rosenholtz'a (1985) göre; kendini mesleki olarak geliştirmede başarılı olan yöneticiler kendi yetenek ve becerileriyle ilgili olarak daha fazla kendine güven duygusu geliştirmektedirler. Sonuç olarak okul yöneticiliği mesleğine ön hazırlık, mesleğe seçilme ve giriş kriterleri, profesyonel mesleki gelişimin esaslarının ve içeriklerinin oluşturulması, meslek onurunun korunması, mesleki dayanışmanın sağlanması, özlük hakları, çalışma koşulları, yetki, hak ve sorumlulukların sınırlarının belirlenmesi konusunda okul yöneticilerinin inisiyatif alabildiği bir ortamın oluşturulması gerekmektedir (Karataş, Radmard, Öksüz-Gül, Varol ve Dă̆, 2019).

Okul yöneticilerininkişisel ve mesleki gelişimlerinin okul amaçları doğrultusunda etkili bir şekilde sağlanması için, mesleki gelişim etkinliklerinden yüksek düzeyde yararlanmaları önemlidir. Kendisini sürekli yenileme çabasında olan okul yöneticilerinin eğitim personeli dışında öğrenci ve velileri de olumlu etkilemesi söz konusudur. Böylece, bu araştırmayla okul yöneticilerinin gelecekte katılacakları mesleki gelişim etkinliklerinin etkili bir şekilde yürütülebilmesi için planlanmaları, uygulanmaları ve değerlendirilmesine yönelik ipuçları bakımından da önemli olduğu düşünülmektedir. Bu araştırma ile okul yöneticilerinin kendi mesleki gelişim etkinliklerine ilişkin algılarının belirlenmesi amaçlanmaktadır. Bu amaç doğrultusunda okul yöneticilerinin;

i) Katıldıkları mesleki gelişim etkinlik türleri, mesleki gelişim etkinliklerine katılma durumları, mesleki gelişim etkinliklerinden etkilenme düzeyleri, mesleki gelişim etkinliklerine katılma süreleri, kişisel olarak gerçekleştirdikleri mesleki gelişim etkinlik türleri, ihtiyaç duydukları mesleki gelişim etkinlik alanları, mesleki gelişim etkinliklerine katılma talepleri, mesleki gelişim etkinliklerine katılamama nedenleri ve mesleki gelişim etkinliklerinde sunulan ücret desteği nedir?

ii) Mesleki gelişim etkinliklerine katılma süreleri, katılım sayıları ve mesleki gelişim etkinliklerinden etkilenme düzeyleri cinsiyet, görev yaptıkları okul türü ve yaş değişkenlerine göre anlamlı farklılık göstermekte midir?

iii)Mesleki gelişim etkinliklerine katılma sayıları, katılım süreleri ve mesleki gelişim etkinliklerinden etkilenme düzeyleri arasındaki ilişkiler nedir? sorularına yanıt aranmaktadır.

\section{Yöntem}

Okul yöneticilerinin kendi mesleki gelişim etkinliklerine ilişkin algılarını belirlemeyi amaçlayan bu araştırma, genel tarama modelinde tasarlanmıştır. Tarama modelindeki araştırmalar, belli özelliklere sahip bir grup bireyin olay, olgu ve durumlara yönelik algı ve tutumlarını tespit etmeyi amaçlayan nicel araştırma yöntemlerinden biridir (Fraenkel, Wallen ve Hyun, 2012).

\section{Araştırmada İzlenilen Etik ilkeler}

Akdeniz Üniversitesi ile Antalya İl Milli Eğitim Müdürlüğü arasında 10 Ekim 2016 tarihinde yürürlüğe giren eğitim işbirliği protokolü kapsamında, araştırmanın yürütüldüğü birimlere bağlı olan kurumlardan yasal izinler alınmış olup; verilerin toplanması, 17-18 Nisan 2017 tarihlerinde düzenlenen “Okul Yönetimi 
Seminer"inde araştırmacı tarafından gerçekleştirilmiştir. Araştırmanın uygulama aşamasında okul yöneticilerine araştırma hakkında detaylı açıklayıcı bilgiler hem sözlü hem de yazılı bir şekilde sunulmuştur. Araştırmaya katılımlarının gönüllülük esasına dayalı olarak gerçekleştirileceği belirtilerek özerklik ilkesine dikkat edilmiştir. Okul yöneticilerinden elde edilen kimlik ve araştırma sorularına ait bilgilerin korunmasına yönelik gizlilik ilkelerine uyulacağı konusunda da bilgilendirilmişlerdir.

\section{Çalışma grubu}

$\mathrm{Bu}$ araştırmanın çalışma evreninde Antalya ili Kemer, Korkuteli ve Serik ilçelerinde yer alan devlet ilkokulu, ortaokulu ve liselerinde görev yapan ve "Okul Yönetimi Semineri" ne katılan 127 okul yöneticisi yer almaktadır. Araştırmanın örnekleminde basit seçkisiz örnekleme yöntemine göre belirlenen 100 okul yöneticisi bulunmaktadır. Okul yöneticilerinin 18'i kadın ve $82^{\prime}$ si erkektir. Katılımcıların 47'si ilkokul, 44'ü ortaokul ve 9'u lise de okul yöneticisi olarak görev yapmaktadır. Yaş bilgisini paylaşan 77 katılımcının yaş değişkenine göre dağılımları incelendiğinde, 11'i 35 yaş ve altında, 13'ünün 36-40 yaş aralığında, 20'sinin 4145 yaş aralığında, 17'sinin 46-50 yaş aralığında ve 16'sının 51 yaş ve üstünde olduğu görülmektedir (Tablo 1).

Tablo I

Kimlik değişkenlerine ilişkin bilgiler

\begin{tabular}{|c|c|c|c|c|c|c|c|}
\hline & & 1 & 2 & 3 & 4 & 5 & Toplam \\
\hline \multirow{2}{*}{ Cinsiyet } & & Kadın & Erkek & & & & \\
\hline & $\mathrm{n}$ & 18 & 82 & & & & 100 \\
\hline \multirow{2}{*}{ Okul türü } & & İlkokul & Ortaokul & Lise & & & \\
\hline & $\mathrm{n}$ & 47 & 44 & 9 & & & 100 \\
\hline \multirow{2}{*}{ Yaş } & & 35 yaş ve altı & $36-40$ yaş & $41-45$ yaş & $46-50$ yaş & 51 yaş ve üstü & \\
\hline & $\mathrm{n}$ & 11 & 13 & 20 & 17 & 16 & 100 \\
\hline
\end{tabular}

\section{Veri toplama arac1}

Araştırmada veriler, "Mesleki Gelişim Etkinliği" anketi ile toplanmıştır. "Mesleki Gelişim Etkinliğii" anketi, TALIS [Teaching and Learning International Survey- Uluslararası Öğretme ve Öğrenme Araştırması] (2008) Uluslararası Öğretme ve Öğrenme Anketi'nde (MEB, 2010) i) kişisel bilgiler ve ii) mesleki gelişim kategorilerinde yer alan bilgilerden elde edilmiştir. TALIS, 23 OECD ülkesinde öğretmenlerin çalışma koşullarına odaklanan ve okullardaki öğrenme ortamını araştıran uluslararası bir çalışmadır. Ülkelerin etkili okulları yaratmak için politikalarını ve mevcut durumlarını gözden geçirmelerini sağlamak amacıyla öğretmen ve okul yöneticilerinden oluşan çalışma gruplarından veriler toplanmaktadır (MEB, 2010). "Mesleki Gelişim Etkinliği" anketinin i) kişisel bilgiler kategorisinde okul yöneticilerinin cinsiyet, görev yaptıkları okul türü ve yaş değişkenlerine yönelik üç soru bulunmaktadır. ii) Mesleki gelişim kategorisinde ise okul yöneticilerinden son 18 aylık dönemi içerisinde mesleki gelişim etkinliklerine katılma durumlarına, etkilenme düzeylerine yönelik yedi soruyu cevaplamaları istenmiştir. Ayrıca, bu kategoride okul yöneticilerine mesleki gelişim etkinliklerine katılma süreleri, kişisel olarak gerçekleştirdikleri mesleki gelişim etkinlik türleri, ihtiyaç duydukları mesleki gelişim etkinlik alanları, mesleki gelişim etkinliklerine katılma talepleri, mesleki gelişim etkinliklerine katılamama nedenleri ve mesleki gelişim etkinliklerinde sunulan ücret desteğine yönelik altı soru yer almaktadır.

Okul yöneticilerinin Mesleki Gelişim Etkinliklerine Katılma Sayıları (MGESy) katılma durumları için "1" katılmama durumları için " 0 " şeklinde derecelendirme ile gerçekleştirilmiştir. Mesleki Gelişim Etkinliklerinin Okul Yöneticilerine Etkileri (MGEEDz); etkisi yok için "0", az etkisi var için "1", orta düzeyde etkisi var için "2" ve çok düzeyde etkisi var için "3" şeklinde derecelendirme ile belirlenmiştir. Bu araştırma için yapı geçerliğini belirlemek amacıyla, gerçekleştirilen doğrulayıcı faktör analizi sonucunda da, elde edilen modelin uyum indeksleri MGESy için [ $\chi 2(\mathrm{sd}=14)=15,05 ; \mathrm{p}<0,05], \mathrm{RMSEA}=0,27 ; \mathrm{GFI}=0,96$; AGFI = 0,92; NNFI = 0,95 ve $\mathrm{CFI}=0,97$ olarak bulunmuştur. Faktör madde ilişkisini gösteren standardize katsayılar $\lambda=0.25-\lambda=0.65$ arasında değişim göstermiştir. MGEEDz için, elde edilen modelin uyum indeksleri [ $\chi 2$ (sd=14) =22,23, p<0,05], RMSEA $=0,77$; GFI $=0,94$; AGFI $=0,88$; NNFI $=0,79$ ve $C F I=0,86$ 'dır. Faktör madde ilişkisini gösteren standardize katsayılar da, $\lambda=0,22-\lambda=0,74$ arasında değişim göstermiştir. Bu çalışmada, ölçeğin Cronbach alfa iç tutarlılık katsayısı MGESy'yi oluşturan tüm maddeler için 0,68 veMGEEDz'yi oluşturan tüm maddeler için 
de 0,621 olarak hesaplanmıştır.

\section{Verilerin toplanması ve analizi}

Veriler Antalya ili Kemer, Korkuteli ve Serik ilçelerinde devlet ilkokulu, ortaokulu ve liselerinde görev yapan ve 2016-2017 eğitim öğretim yılı bahar döneminde düzenlenen "Okul Yönetimi Semineri” ne katılan okul yöneticilerinden 18-19 Nisan 2017 tarihleri arasında toplanmış; verilerin analizinde SPSS 13.0 ve LISREL 8.53 paket programlarından yararlanılmıştır. Araştırmanın kişisel bilgiler ve mesleki gelişim kategorisinde yer alan betimsel istatiksel verileri için frekans, yüzde dağılımı, aritmetik ortalama ve standart sapma değerlerine yer verilmiştir. Bununla birlikte okul yöneticilerinin mesleki gelişim etkinliklerine katılma süreleri, katılım sayları ve mesleki gelişim etkinliklerinden etkilenme düzeylerinin cinsiyet değişkenine göre karşılaştırılmasında normallik sayıltıları ve varyansların homojenliği ihlal ettiği Mesleki Gelişim Etkinliklerine Katılım Süresi (MGEKSr) için Kolmogorov-Smirnov (K-S) testi = 0,276; p<0,05; MEGSy için KolmogorovSmirnov (K-S) testi $=0,175$; $\mathrm{p}<0,05$ ve MGEEDz için Kolmogorov-Smirnov (K-S) testi=0,129; $\mathrm{p}<0,05^{\prime}$ dir.) için non-parametrik testlerden Mann-Whitney $U$ testi kullanılmıştır. Görev yaptıkları okul türü ve yaş değişkenlerine göre karşılaştırılmasında ise Kruskal Wallis $\mathrm{H}$ testinden yararlanılmıştır. Okul yöneticilerinin mesleki gelişim etkinliklerine katılma sayıları, katılım süreleri ve mesleki gelişim etkinliklerinden etkilenme düzeyleri arasındaki ilişkiler Pearson Momentler Çarpım korelasyon katsayıları ile incelenmiştir.

\section{Bulgular}

Bu bölüm, üç alt bölümden oluşmaktadır: Okul yöneticilerinin 1)katıldıkları mesleki gelişim etkinlik türleri, mesleki gelişim etkinliklerine katılma durumları, mesleki gelişim etkinliklerinden etkilenme düzeyleri, mesleki gelişim etkinliklerine katılma süreleri, kişisel olarak gerçekleştirdikleri mesleki gelişim etkinlik türleri, ihtiyaç duydukları mesleki gelişim etkinlik alanları, mesleki gelişim etkinliklerine katılma talepleri, mesleki gelişim etkinliklerine katılamama nedenleri ve mesleki gelişim etkinliklerinde sunulan ücret desteği, 2)Mesleki gelişim mesleki gelişim etkinliklerine katılma süreleri, katılım sayıları ve mesleki gelişim etkinliklerinden etkilenme düzeylerinin cinsiyet, görev yaptıkları okul türü ve yaş değişkenlerine göre farklılaşmakta durumları, 3)Mesleki gelişim etkinliklerine katılma sayıları, katılım süreleri ve mesleki gelişim etkinliklerinden etkilenme düzeyleri arasındaki ilişkiler.

Okul yöneticilerinin mesleki gelişim etkinliklerine katılma durumları ve etkinliklerden etkilenme düzeyleri

Okul yöneticilerinin mesleki gelişim etkinliklerine katılma durumları ve bu etkinliklerden etkilenme düzeylerine ilişin frekans değeri Tablo 2’ de yer almaktadır.

Tablo II

Okul yöneticilerinin mesleki gelişim etkinliklerine katılma durumları ve mesleki gelişim etkinliklerinden etkilenme düzeyleri

\begin{tabular}{|c|c|c|c|c|c|c|c|}
\hline \multirow[b]{2}{*}{ Etkinlikler } & \multicolumn{2}{|c|}{ Katılma durumu } & \multicolumn{5}{|c|}{ Etki düzeyi } \\
\hline & Evet & Hayır & $\begin{array}{c}\text { Etkisi } \\
\text { olmadi }\end{array}$ & $\mathrm{Az}$ & Orta & Çok & Toplam \\
\hline Kurslar/çalıştaylar & 65 & 35 & 3 & 10 & 39 & 13 & 65 \\
\hline Eğitim konferansları veya seminerleri & 52 & 48 & 0 & 5 & 35 & 12 & 52 \\
\hline $\begin{array}{l}\text { Diploma/sertifika programları (örneğin lisansüstü } \\
\text { programlar) }\end{array}$ & 20 & 80 & 0 & 6 & 7 & 7 & 20 \\
\hline Diğer okullara yapılan inceleme gezileri & 55 & 45 & 0 & 5 & 33 & 17 & 55 \\
\hline Mesleki gelişimi için oluşturulan çalışma grubu & 32 & 68 & 0 & 4 & 21 & 7 & 32 \\
\hline Meslekî konuda bireysel ya da ortak araştırma yapma & 34 & 66 & 3 & 2 & 18 & 11 & 34 \\
\hline Meslektaşlara rehberlik etme, gözlemleme ve yetiştirme & 42 & 58 & 1 & 2 & 24 & 15 & 42 \\
\hline
\end{tabular}

Tablo 2 incelendiğinde, okul yöneticilerinin en fazla kurslara/çalıştaylara ( $f=65)$ katıldıkları gözlenmiştir. Kurslar/çalıştaylara katılan okul yöneticilerin \%20'si ( $(\mathrm{f}=13)$ bu etkinliklerin kendi mesleki gelişimleri üzerinde çok etkili olduğu kanısındadırlar. Ayrıca, okul yöneticilerinin diğer okullara yapılan inceleme gezilerine (\%55) ve eğitim konferansları veya seminerlerine (\%52) katılım oranları da yüksektir. Okul inceleme gezilerine vakit ayıran okul yöneticilerinin \%87'si $(f=38)$ ve eğitim konferans/seminerlerine vakit ayıran okul yöneticilerinin \%77'si $(f=40)$ de bu etkinliklerin çok etkili düzeyde olmadığı görüşündedir. Okul yöneticilerinin en az katıldıkları 
mesleki gelişim etkinlikleri \%20 oranıla diploma/sertifika programlarına aittir. Buna rağmen diploma/sertifika programlarına katılan okul yöneticilerinin yaklaşık $\% 35^{\prime} \mathrm{i}$ bu etkinliklerin çok etkili ve $\% 30$ 'da hiç ya da az etkisinin olduğunu ifade etmeleri dikkat çekmektedir.

Okul yöneticilerinin katıldıkları mesleki gelişim etkinliği türlerine göre etkililik sıralaması Şekil 1'de yer almaktadır.

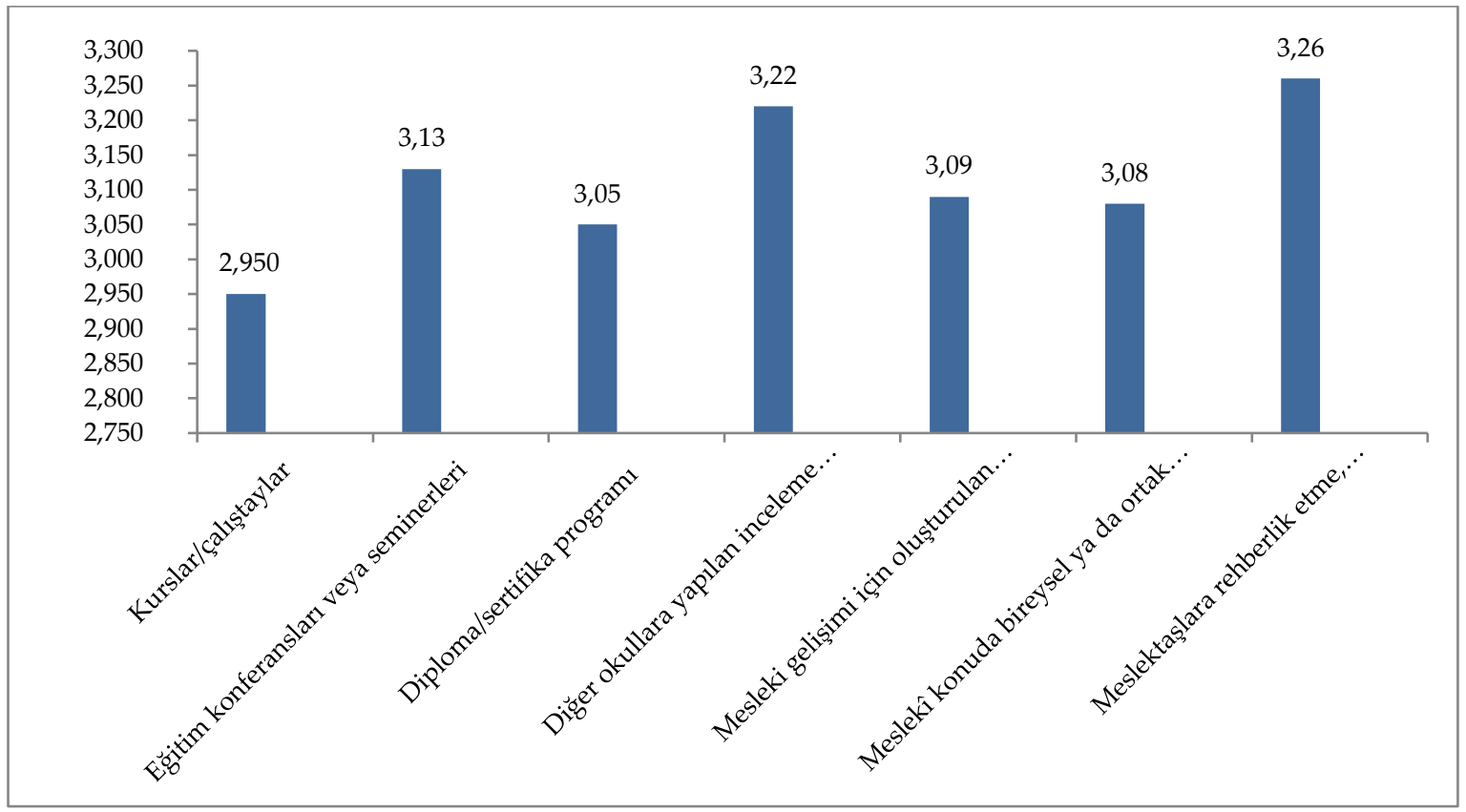

Şekil 1. Okul yöneticilerinin katıldıkları mesleki gelişim etkinliği türlerine göre etkililik sıralaması

Meslektaşlara rehberlik etme, gözlemleme ve yetiştirme $(\overline{\mathrm{X}}=3,26)$, diğer okullara yapılan inceleme gezileri $(\bar{X}=3,22)$ ve eğitim konferansları veya seminerleri $(\bar{X}=3,13)$ okul yöneticilerinin mesleki gelişimleri üzerinde diğer etkinliklere kıyasla daha fazla etkiye sahiptir. En düşük düzeyde etki sıralamasına sahip olan etkinlik ise en fazla katılımın da sağlandığı etkinliklerden biri olan kurslar ve çalıştaylardır $(\bar{X}=2,95)$.

\section{Okul yöneticilerinin mesleki gelişim etkinliklerine katılma süreleri}

Okul yöneticilerinin mesleki gelişim etkinliklerine katılma sürelerine ilişin betimsel istatistikler, Tablo 3'te yer almaktadır.

\section{Tablo III}

Okul yöneticilerinin mesleki gelişim etkinliklerine katılma süreleri

\begin{tabular}{|c|c|c|c|c|c|c|}
\hline & & \multirow[b]{2}{*}{$\mathrm{f}$} & \multicolumn{4}{|c|}{ Betimsel İstatistikler } \\
\hline & & & Aritmetik Ortalama & SS & Min. & Max. \\
\hline \multirow{5}{*}{$\begin{array}{l}\text { Toplam mesleki gelişim } \\
\text { etkinliklerine katılma süresi }\end{array}$} & 1-2 gün & 25 & & & & \\
\hline & 3-8 gün & 28 & & & & \\
\hline & 10-15 gün & 25 & 9,52 & 13,20 & 1 & 80 \\
\hline & $17-80$ gün & 14 & & & & \\
\hline & Cevapsız & 8 & & & & \\
\hline \multirow{5}{*}{$\begin{array}{l}\text { Yöneticilik görevinin bir parçası } \\
\text { olarak mesleki gelişim } \\
\text { etkinliklerine zorunlu olarak } \\
\text { katılma süresi }\end{array}$} & $1-2$ gün & 29 & & & & \\
\hline & 3-8 gün & 32 & & & & \\
\hline & 10-15 gün & 15 & 6,46 & 10,74 & 1 & 80 \\
\hline & 17-80 gün & 8 & & & & \\
\hline & Cevapsiz & 16 & & & & \\
\hline
\end{tabular}

Tablo 3 incelendiğinde, okul yöneticilerinin mesleki gelişim etkinliklerine katılma süreleri ortalama 10 gün olup bunun da ortalama 6 gününün yöneticilik görevlerinin zorunlu bir parçasının oluşturduğu görülmektedir. Okul yöneticileri mesleki gelişim etkinliklerine katıldıkları süre içinde görevlerinin bir parçası olarak ayırdıkları sürenin yaklaşık \%68 oranında olması dikkat çekici bir bulgudur. 


\section{Okul yöneticilerinin kişisel olarak gerçekleştirdikleri mesleki gelişim etkinlikleri, etkinliklere katılma durumları ve etkinliklerinden etkilenme düzeyleri}

Okul yöneticilerinin kişisel olarak gerçekleştirdikleri mesleki gelişim etkinliklere ilişkin frekans değeri Tablo 4 'te yer almaktadır.

\section{Tablo IV}

Okul yöneticilerinin kişisel olarak gerçekleştirdikleri mesleki gelişim etkinliklerine katılma durumlar ve mesleki gelişim etkinliklerinden etkilenme düzeyleri

\begin{tabular}{|c|c|c|c|c|c|c|c|}
\hline \multirow[t]{2}{*}{ Kişisel olarak gerçekleştirilen etkinlikler } & \multicolumn{2}{|c|}{ Katılma durumu } & \multicolumn{5}{|c|}{ Etki düzeyi } \\
\hline & Evet & Hayır & $\begin{array}{l}\text { Etkisi } \\
\text { olmadi }\end{array}$ & $\mathrm{Az}$ & Orta & Çok & Toplam \\
\hline $\begin{array}{l}\text { Mesleki yayınlar okuma (dergiler, makaleler) ve } \\
\text { izleme (film ve tv programı) }\end{array}$ & 78 & 22 & 2 & 8 & 39 & 29 & 78 \\
\hline $\begin{array}{l}\text { Meslektaşlarla mesleki konularda fikir alışverişinde } \\
\text { bulunma }\end{array}$ & 84 & 16 & 4 & 4 & 37 & 39 & 84 \\
\hline
\end{tabular}

Tablo 4 incelendiğinde, okul yöneticilerinin \%84'ü meslektaşlarıyla mesleki konularda fikir alışverişinde bulunduklarını ve \%78'i de mesleki yayınlar okudukları ve izlediklerini belirtmektedirler. Etki düzeyleri değerlendirildiğinde, meslektaşları ile fikir alış verişinde bulunduğunu belirten okul yöneticilerinin yaklaşık $\% 46$ 'sı $(f=39)$ ve mesleki yayınları okuduklarını ve izlediklerini belirten okul yöneticilerinin yaklaşık \%37'si $(f=29)$ etkinliklerin çok etkili olduğunu ifade etmektedirler.

\section{Okul yöneticilerinin ihtiyaç duydukları mesleki gelişim alanları}

Okul yöneticilerinin ihtiyaç duydukları mesleki gelişim alanlarına ilişkin frekans ve yüzde değeri Tablo 5'te yer almaktadır.

Tablo V

Okul yöneticilerinin ihtiyaç duydukları mesleki gelişim alanları

\begin{tabular}{lcc}
\hline Etkinlik türleri & $\mathrm{f}$ & $\%$ \\
\hline Okul (iş) sağlı̆̆ ve güvenliği & 25 & 20,2 \\
Etkili iletişim becerileri & 18 & 14,5 \\
Fark yaratan okul ve eğitim yönetimi uygulamaları & 18 & 14,5 \\
Eğitimde bilgi teknolojilerini kullanma becerisi & 16 & 13 \\
Öğrenci disiplin ve davranış sorunları & 15 & 12 \\
Özel eğitime ihtiyacı olan öğrencilerine yönelik eğitim uygulamaları & 9 & 7,3 \\
Proje yazımı (TUBİTAK, Avrupa Birliği vb.) & 6 & 2,4 \\
Okul yönetiminde muhasebe /Ekonomi okuryazarlığı ve ihaleler & 3 & 2,4 \\
Mevzuat & 3 & 2,4 \\
Sınıf yönetimi & 2 & 1,6 \\
Doküman yönetim sistemi & 2 & 1,6 \\
Protokol kuralları & 2 \\
Materyal geliştirme ve uygulama & 2 \\
Değerler eğitiminde uygulama teknikleri & 2 \\
Öğrenci değerlendirme uygulamaları & 1,6 \\
\hline Toplam & 1 & 1,6 \\
\hline
\end{tabular}

Tablo 5 incelendiğinde, okul yöneticilerinin \%20,2'si okul (iş) sağglı̆̆ ve güvenliği, \%14,5'i etkili iletişim becerileri ile fark yaratan okul ve eğitim yönetimi uygulamaları, \%13'ü eğitimde bilgi teknolojilerini kullanma becerisi ve \%12'si de öğrenci disiplin ve davranış sorunları konularında mesleki gelişime ihtiyaç duyduklarını belirtmektedirler. En az ihtiyaç duydukları mesleki gelişim konuları sınıf yönetimi $(f=2)$, dokuman yönetim sistemi $(f=2)$, protokol kuralları $(f=2)$, materyal geliştirme ve uygulama $(f=2)$, değerler eğitiminde uygulama teknikleri $(f=2)$ ve öğrenci değerlendirme uygulamalarıdır $(f=1)$.

\section{Okul yöneticilerinin mesleki gelişim etkinlikleri talepleri}

Okul yöneticilerinin mesleki gelişim etkinlikleri taleplerine yönelik görüşlerin yüzde dağılımları Şekil 2'de yer almaktadir. 


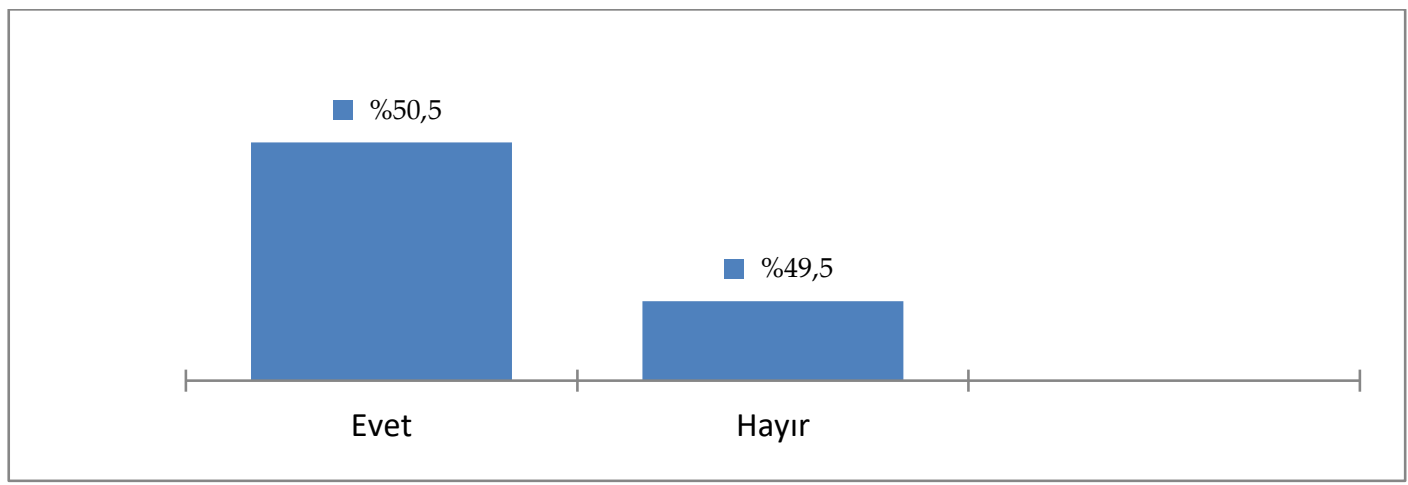

Şekil 2. Okul yöneticilerinin mesleki gelişim etkinlikleri talepleri

Şekil 2 incelendiğinde, okul yöneticilerinin \%50,5'i $(f=49)$ mesleki gelişim etkinliklerine daha fazla katılmak isterken; \%49,5'i ( $f=48)$ mesleki gelişim etkinliklerine katılmakistememektedir.

\section{Okul yöneticilerinin mesleki gelişim etkinliklerine katılamama nedenleri}

Okul yöneticilerinin mesleki gelişim etkinliklerine katılamama nedenlerine ilişkin frekans ve yüzde değerleri Tablo 6'da yer almaktadır.

\section{Tablo VI}

Okul yöneticilerinin mesleki gelişim etkinliklerine katılamama nedenleri

\begin{tabular}{lcc}
\hline & $\mathrm{f}$ & $\%$ \\
\hline Uygun bir mesleki gelişim etkinliğinin olmaması & 40 & 67,8 \\
Ailevi sorumluluklarından dolayı vakit olmaması & 11 & 18,6 \\
Mesleki gelişim etkinliğinin çok pahalı olması/Karşılayamama & 8 & 13,6 \\
Toplam & 59 & 100 \\
\hline
\end{tabular}

Tablo 6 incelendiğinde, okul yöneticilerinin uygun bir mesleki gelişim etkinliğinin olmaması $(f=40)$ görüşüne katılma oranları en fazladır. Bu durumu sirasıyla, \%18,6 oranıla ailevi sorumluluklarından dolayı vaktin olmaması ve \%13,6 oranıla mesleki gelişim etkinliğinin çok pahalı olması/karşılayamama nedenleri izlemektedir.

\section{Okul yöneticilerine sunulan ücret desteği}

Okul yöneticilerinin mesleki gelişim etkinliklerine katılmalarını sağlamak için sunulan ücret desteğine ilişkin yüzde dağılımlar Şekil 3’te yer almaktadır.

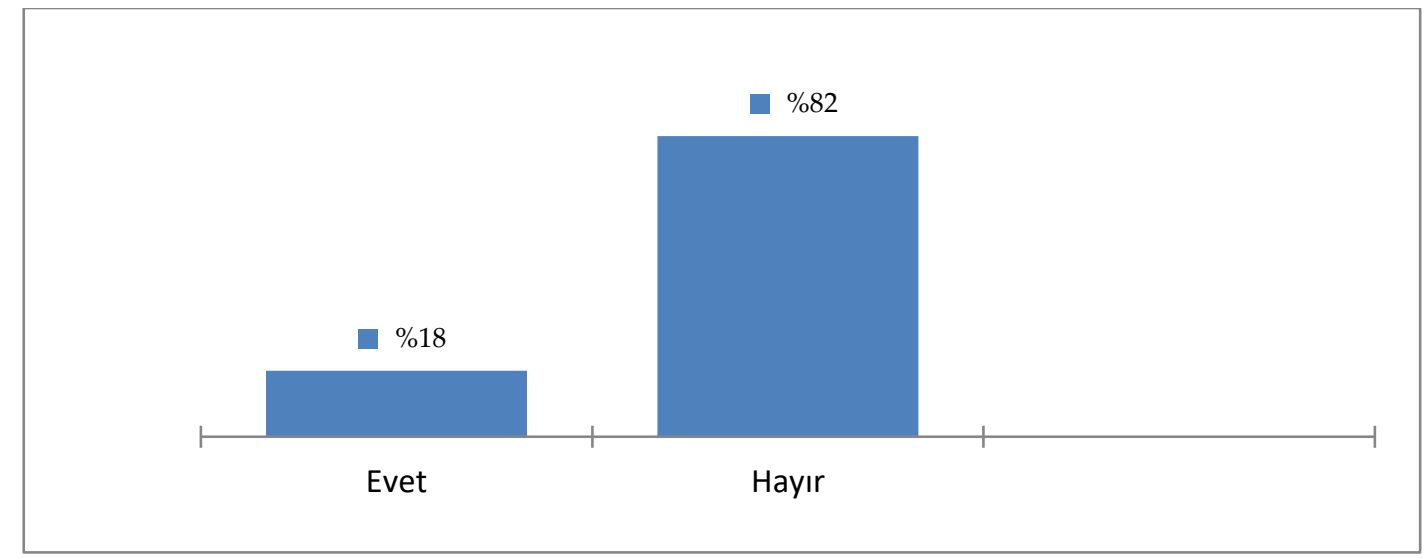

Şekil 3. Okul yöneticilerinin mesleki gelişim etkinliklerine katılmalarını sağlamak için sunulan ücret desteği

Şekil 3'te okul yöneticilerinin \%18'ine mesleki gelişim etkinliklerine katılımlarını sağlamak için ücret desteğinin sağlandığı ve \%82'sine de ücret desteğinin sağlanmadığıgörülmektedir. 
Okul yöneticilerinin mesleki gelişim etkinliklerine katılma süreleri ve katılım sayıları ile mesleki gelişim etkinliklerinden etkilenme düzeylerinin cinsiyet, görev yaptıkları okul türü ve yaş değişkenlerine göre farklılaşması

Kadın ve erkek okul yöneticilerinin mesleki gelişim etkinliklerine katılma sayıları, katılma süreleri ve mesleki gelişim etkinliklerindenetkilenmedüzeylerinin karşılaştırılması amacıyla Mann-Whitney $U$ testi yapılmış ve sonuçlar Tablo 7'de verilmiştir.

Tablo VII

Cinsiyete göre okul yöneticilerinin mesleki gelişim etkinliklerine katılma sayıları, katılım süreleri ve etkinliklerden etkilenme düzeylerine ilişkin MannWhitney U testi sonuçları

\begin{tabular}{lcccccc}
\hline Değişkenler & \multicolumn{2}{c}{ Sıra ortalamaları } & \multicolumn{2}{c}{ Sira toplamları } & \multirow{2}{*}{$\mathrm{U}$} & $\mathrm{p}$ \\
& Kadın $(\mathrm{n}=18)$ & Erkek $(\mathrm{n}=82)$ & Kadın $(\mathrm{n}=18)$ & Erkek $(\mathrm{n}=82)$ & 4100,00 & 679,000 \\
\hline MGESy & 47,22 & 50,62 & 850,00 & 648 \\
MGEKSr & 52 & 50,17 & 936,00 & 4114,00 & 711,000 &, 806 \\
MGEEDz & 42,53 & 52,25 & 765,50 & 4284,50 & 594,500 &, 196 \\
\hline
\end{tabular}

MGEKSr: Etkinliklere Katılım Süresi, MGESy: Etkinliklere Katılma Sayısı, MGEEDz: Etkinliklerden Etkilenme Düzeyi

Tablo 7 incelendiğinde, cinsiyet değişkeni açısından mesleki gelişim etkinliklerine katılma sayıları $(U=711,000 ; p>0,05)$, katılma süreleri $(U=679,000 ; p>0,05)$ ve etkinliklerden etkilenme düzeyleri $(U=594,500$; $\mathrm{p}>0,05$ ) istatistiksel olarak anlamlı değildir.

İlkokul, ortaokul ve liselerde görev yapan okul yöneticilerinin mesleki gelişim etkinliklerine katılma sayıları, katılma süreleri ve mesleki gelişim etkinliklerinden etkilenme düzeylerinin karşılaştırılması amacıyla Kruskal Wallis H testi yapılmış ve sonuçlar Tablo 8'de verilmiştir.

Tablo VIII

Görev yapılan okul türüne göre okul yöneticilerinin mesleki gelişim etkinliklerine katılma sayıları, katılım süreleri ve etkinliklerden etkilenme düzeylerine ilişkin Kruskal Wallis H testi sonuçları

\begin{tabular}{|c|c|c|c|c|c|c|c|}
\hline \multirow[t]{2}{*}{ Değişkenler } & \multicolumn{3}{|c|}{ Sira ortalamaları } & \multirow{2}{*}{ sd } & \multirow{2}{*}{ KWH } & \multirow{2}{*}{$\mathrm{p}$} & \multirow{2}{*}{ Anlamlı Fark } \\
\hline & $\dot{\mathrm{I}}(\mathrm{n}=47)$ & $\mathrm{O}(\mathrm{n}=44)$ & $\mathrm{L}(\mathrm{n}=9)$ & & & & \\
\hline MGEKSr & 45,39 & 49,76 & 75,22 & & 8,265 & ,016 & L-I, L-O \\
\hline MGESy & 58,22 & 46,03 & 32,00 & 2 & 8,292 & ,016 & I-L \\
\hline MGEEDz & 43,49 & 53,03 & 74,72 & & 9,428 & ,009 & L-I, L-O \\
\hline
\end{tabular}

$\dot{I}=\dot{I} l k o k u l, O=O r t a o k u l, L=$ Lise

Tablo 8 incelendiğinde, görev yapılan okul türüne göreokul yöneticilerinin mesleki gelişim etkinliklerine katılma sayıları $(\mathrm{KWH}(2)=8,292 ; \mathrm{p}<0,05)$, katılma süreleri $(\mathrm{KWH}(2)=8,265 ; \mathrm{p}<0,05)$ ve etkinliklerden etkilenme düzeyleri $(\mathrm{KWH}(2)=9,428$; p<0,05)istatistiksel olarak anlamlıdır. Anlamlı farklılığın hangi gruplardan kaynaklandığını belirlemek üzere Mann Whitney U testi yapılmıştır. Buna göre mesleki gelişim etkinliklerine katılma sayıları, ilkokul ve liselerde görev yapan okul yöneticileri arasında anlamlı farklılıklar göstermektedir. Başka bir ifade ile ilkokullarda görev yapan okul yöneticileri liselerde görev yapmakta olan okul yöneticilerine göre mesleki gelişim etkinliklerine katılma sayılarının daha fazla olduğundan bahsedilebilir. Ayrıca, okul yöneticilerinin mesleki gelişim etkinliklerden etkilenme düzeyleri ve etkinliklere katılma süreleri ise, lise ile ilkokul ve lise ile ortaokullarda görev yapan okul yöneticileri arasında anlamlı farklılıklar göstermektedir. Başka bir ifade ile liselerde görev yapan okul yöneticileri ilkokul ve ortaokullarda görev yapan okul yöneticilerine göre, mesleki gelişim etkinliklerini daha etkili görmekte ve etkinliklere katılma süreleri daha fazladir.

Yaş değişkenine göre okul yöneticilerinin mesleki gelişim etkinliklerine katılma sayıları, katılma süreleri ve mesleki gelişim etkinliklerinden etkilenmedüzeylerinin karşılaştırılması amacıylayapılan Kruskal Wallis $\mathrm{H}$ testi sonuçları Tablo 9'da yer almaktadır.

\section{Tablo IX}

Yaş değişkenine göre okul yöneticilerinin mesleki gelişim etkinliklerine katılma sayıları, katılım süreleri ve etkinliklerden etkilenme düzeylerine ilişkin Kruskal Wallis H testi sonuçları

\begin{tabular}{|c|c|c|c|c|c|c|c|}
\hline \multirow{2}{*}{ Değişkenler } & \multicolumn{3}{|c|}{ Sira ortalamaları } & \multirow{2}{*}{$\mathrm{sd}$} & \multirow{2}{*}{$\mathrm{KWH}$} & \multirow{2}{*}{$\mathrm{p}$} & \multirow{2}{*}{ Anlamlı Fark } \\
\hline & 40 yaş ve altı & $41-50$ yaş(n=37) & 51 ve üstü & & & & \\
\hline
\end{tabular}




\begin{tabular}{|c|c|c|c|c|c|c|c|}
\hline & $(\mathrm{n}=24)$ & & $(n=16)$ & & & & \\
\hline MGEKSr & 36,63 & 39,81 & 40,69 & & 1,680 & ,432 & - \\
\hline MGESy & 37,96 & 40,14 & 37,94 & 2 & ,423 & 809 & - \\
\hline MGEEDz & 37,96 & 41,24 & 32,60 & & 185 & ,912 & - \\
\hline
\end{tabular}

Tablo 10 incelendiğinde, yaş değişkenine göre okul yöneticilerinin mesleki gelişim etkinliklerine katılma sayıları [KWH (2) =0,423; p>0,05 ], katılma süreleri [KWH (2) =1,680; p>0,05 ] ve etkinliklerden etkilenme düzeyleri $[\mathrm{KWH}(2)=0,185 ; \mathrm{p}>0,05]$ istatistiksel olarak anlamlı değildir.

\section{Okul yöneticilerinin mesleki gelişim etkinliklerine katılma sayıları, katılım süreleri ve etkinliklerden etkilenme düzeyleri arasındaki ilişkiler}

Okul yöneticilerinin mesleki gelişim etkinliklerine katılma sayıları, katılım süreleri ve etkinliklerden etkilenme düzeyleri arasındaki ilişkilere yönelik araştırma bulguları Tablo 10'da yer almaktadır.

Tablo X

Okul yöneticilerinin mesleki gelişim etkinliklerine katılma sayıları, katılma süreleri ve etkinliklerden etkilenme düzeyleri arasındaki ilişki

\begin{tabular}{lccc}
\hline & Katılma sayıları & Etkilenme düzeyi & Katılma süreleri \\
\hline Katılma sayıları & 1 & & \\
Etkilenme düzeyi & $-0,779\left(^{* *}\right)$ & 1 & 1 \\
Katılma süreleri & $-0,185$ & $0,233\left(^{*}\right)$ & 1 \\
\hline
\end{tabular}

${ }^{*} p<0.05,{ }^{* *} p<0.01$

Tablo 10 incelendiğinde, okul yöneticilerinin mesleki gelişim etkinliklerine katılım sayıları ile bu etkinliklerden etkilenme düzeyleri arasında negatif yönde yüksek bir ilişki $(r=-0,779 ; p<0,05)$ bulunmaktadır. Ayrıca, okul yöneticilerinin bu etkinliklere katılma süreleri ile bu etkinliklerden etkilenme düzeyleri arasında pozitif yönde düşük bir ilişki ( $\mathrm{r}=0,233 ; \mathrm{p}<0,05)$ bulunmaktadır. Son olarak, okul yöneticilerinin mesleki gelişim etkinliklerine katılma sayıları ile katılma süresi arasındaki ilişki istatiksel olarak anlamlı değildir ( $\mathrm{r}=-0,176$; $\mathrm{p}<0,05)$.

\section{Sonuç ve Tartışma}

Bu araştırmanın amacı, okul yöneticilerinin katıldıkları mesleki gelişim etkinlikleri hakkındaki algılarını ortaya koymaktır. Bu amaç doğrultusunda araştırmada, okul yöneticilerinin katıldıkları mesleki gelişim etkinlik türleri, mesleki gelişim etkinliklerine katılma durumları, mesleki gelişim etkinliklerinden etkilenme düzeyleri, mesleki gelişim etkinliklerine katılma süreleri, kişisel olarak gerçekleştirdikleri mesleki gelişim etkinlik türleri, ihtiyaç duydukları mesleki gelişim etkinlik alanları, mesleki gelişim etkinliklerine katılma talepleri, mesleki gelişim etkinliklerine katılamama nedenleri ve mesleki gelişim etkinliklerinde sunulan ücret desteği belirlenmiştir. Ayrıca, okul yöneticilerinin mesleki gelişim etkinliklerine katılma süreleri, katılım sayıları ve mesleki gelişim etkinliklerinden etkilenme düzeyleri cinsiyet, görev yaptıkları okul türü ve yaş değişkenlerine göre anlamlı farklılıkları incelenmiştir. Son olarak, okul yöneticilerinin mesleki gelişim etkinliklerine katılma sayıları, katılım süreleri ve mesleki gelişim etkinliklerinden etkilenme düzeyleri arasındaki ilişkiler ele alınmıştır.

Okul yöneticileri son 18 ay içerisinde ortalama 10 gün mesleki gelişim etkinliklerine katılmışlardır. Katıldıkları bu etkinliklerin 6 gününü ise yöneticilik görevlerinin zorunlu bir parçası oluşturmuştur. En fazla katılım gösterilen mesleki gelişim etkinlikleri içinde kurslar/çalıştaylar, okul inceleme gezilerive eğitim konferans/ seminerleri bulunmaktadır. Okul yöneticilerinin mesleki gelişimlerinin çalıştaylar, geziler, kurum ziyaretleri, lisansüstü eğitim, seminer ve konferanslar ve üniversite işbirliği ile sağlandığını belirten araştırmaların bulguları (Can ve Köse, 2015; Dalgıç, 2011; Gürkan ve Toprakçı, 2018; Nasreen ve Odhiambo, 2018; Polat ve diğerleri, 2018), bu araştırmanın bulgularını desteklemektedir. Özellikle okul inceleme gezileri okullar arası iletişim ağlarını geliştirmek, eğitimcilerin sosyalleşmesini sağlamak, yöneticilerin liderlik becerilerini geliştirmek, bilgi ve tecrübeleripaylaşmak açısından önemli görülmektedir (Edge ve Mylopoulos, 2008). Okul yöneticileri mesleklerinin gerektirdiği bilgi ve becerinin onlara yeteri kadar verilmediğinden dolayı göreve başladıklarında mesleklerini daha iyi yapabilmeleri için eğitim konferans/ seminerlerine ihtiyaç duymaktadırlar (Özus, 2005). Mesleki gelişim etkinlikleri içinde etki düzeyi yüksek olan diploma/sertifika türü 
programlarınakatılım durumu ise en düşüktür. Başka bir ifadeyle, okul yöneticilerinin lisansüstü eğitime katılım durumları kısıtlı olduğundan bahsedilebilir. Amerika ve Avrupa ülkelerinde okul yöneticilerinin lisansüstü eğitim almış olmaları ve her beş yılda bir kez de liderlik kurslarına katılarak gelişimlerini devam ettirmeleri gerekmektedir (Akın, 2012; Balcı, Memduhoğlu, İlgan, Erdem ve Taşdan, 2007; Balyer ve Gündüz, 2011). Dolayısıyla, okul yöneticilerinin ihtiyaç duydukları alanda lisansüstü eğitim almaları özendirilmeli ve teşvik edilmelidir. Böylece okul yöneticileri lisansüstü eğitim sürecine katılarak okul kültürü ve iklimini daha iyi anlayabilecek, kuram ve uygula arasındaki ilişkilerini bir temele oturtabilecek ve kendilerini ve yaptıkları işi daha iyi ifade edebileceklerdir (Dalgıç, 2011).

Okul yöneticilerinin mesleki gelişim etkinliklerinden etkilenme durumları en yüksek düzeyde meslektaşlara rehberlik etme, gözlemleme ve yetiştirmeye aittir. Okul liderleri olarak okul yöneticilerinin kendi kişisel ve mesleki gelişim düzeylerinin öğretmenyetiştirme önemli bir yeri vardır (Polat ve diğerleri, 2018; Pürçek, 2015). Meslektaşlara rehberlik etme, gözlemleme ve yetiştirme ile okul yöneticilerinin mentorlük ve koçluk rolünün önemine vurgu yapılabilir. Fazio'a (2009) göre, profesyonel bir koçun gruba eşlik etmesi, koçun yönlendirmeleri sayesinde öğrenme sürecini daha amaçlı ve planlı bir hale getirip hızlandırmaktadır. Sezgin, Koşar ve Er (2014) araştırmalarında, okul müdürlerinin okul yöneticisi ve öğretmenlerin mesleki ve kişisel gelişimlerine hizmet içi eğitim ve diğer eğitim programlarına yönlendirmelerde bulunarak katkıda bulunduklarını ifade etmiştir. Okul müdürlerinin ilk yıllarında daha tecrübeli okul liderleri tarafından rehberlik edilmeye gerek ihtiyaç duyduklarını belirten araştırma bulguları da yer almaktadır (Aydın, 2015; Connelly, 2008). Dolayısıyla, okul yöneticilerinin niteliğini artırmanın en etkin yolları arasında meslektaşlara rehberlik etme, gözlemleme ve yetiştirme etkinliklerinin görülmesi anlamlıdır. Okul yöneticilerinin mesleki gelişimlerinde en düşük düzeyde etki sıralamasına sahip olan etkinlik ise en fazla katılımın da sağlandığ etkinliklerden biri olan eğitim konferansları veya seminerine aittir. MEB Eğitimi Araştırma ve Geliştirme Dairesi Başkanlığı [EAGDB] tarafından gerçekleşen Hizmet içi Eğitim Faaliyetlerinin Değerlendirilmesi araştırmasında okul yöneticileri hizmet içi eğitimlerin karşılaştıkları mesleki sorunların çözümünü sağlamada orta düzeyde etkisinin olduğunu belirtmişlerdir (MEB, 2006). Eğitim seminerlerini sunan ve yürüten uzmanların gerekli yeterliklere sahip olmadığı düşüncesi mesleki gelişim etkinliklerinin etkinliğini ve uygulanabilirliğini olumsuz yönde etkilemektedir (Daldal, 2016; Urlunç, 2007; Yılmaz ve Esen, 2015). Bununla birlikte hizmet içi eğitimlerde verilen kuramsal bilgiler yetersiz olup, öğrenilen bilgiler uygulamada ve kariyer planlanmasında kullanılmamaktadır. Bunun sebebi, hizmet içi eğitimlerin kurumun kariyer gelişimine olan katkısının az olması ve kişi kariyerine etki etmemesi ile açıklanmaktadır (Daldal, 2016). Ayrıca, okul yöneticilerinin bilgi, beceri ve tutumlarını geliştirmek amacıyla gerçekleşen eğitim konferansları veya seminerine katılımın etkinliğinin düşük olması, mesleki gelişimlerine beklenilen düzeyde katkı sağlanamaması ile de açıklanabilir. Dolayıyla mevcut mesleki gelişim etkinlikleri planlanırken mesleki gelişim etkinliklerinden etkili olanlarının tercih edilmesi önerilebilir. Bermúdez'a (2003) göre, etkili bir hizmet içi eğitim programı ile, bireyler yaptıkları görevlere ait ortak dili edinecek ve mesleki empati becerilerini geliştireceklerdir. Okul yöneticilerinin mesleki gelişim gereksinimlerinin tespitinin daha etkili bir şekilde yürütülmesi için planlı bir mesleki gelişim eğitim politikası ve görevlendirilen öğreticilerin alanında uzman kişiler arasında yer alması ile okul yöneticiler mesleki gelişim etkinliklerine özendirilebilir.

Okul yöneticilerinin resmi yönü olmayan kişisel mesleki gelişim etkinlikleri arasında en yaygın katılım ve çok yüksek düzeyde etkilenilen etkinlik meslektaşlarla fikir alışverişidir. Polat ve diğerleri (2018) meslektaş dayanışması ve meslektaşlarından alınan yardımın okul yöneticilerinin değişme, gelişme ve yenileşme ihtiyaçlarını karşıladığı ve kendi mesleki gelişimlerini sürdürülebilirliklerine imkân sunduğu için önemli olduğunu vurgulamışlardır. Ayrıca, meslektaş dayanışması ile okul yöneticilerinin öğretmen liderliği becerileri de desteklenmiş olacaktır (Sinha ve Hanuscin, 2017). Dalgıç'ın (2011) okul yöneticilerinin yansıtıcı düşünme beceri ve uygulamalarını incelediği araştırmasında, yöneticilerin mesleği öğrenmelerinde eskiden görev yaptıkları okuldaki okul yöneticileri ile meslektaşlardan öğrenmenin büyük etkilerinin olduğu vurgulanmıştır. Gümüş (2019) araştırmasında, yeni okul müdürlerinin mesleki gelişimlerinde deneyimli ve iyi örnekleri teşkil eden çalışan ya da emekli müdürlerinin önemli rollerinin olduğunu ifade etmektedir. Okul yöneticileri arasında mesleki işbirliğinin artması, eğitim personelinin kendi arasındaki ilişkilerinin yanı sıra öğrenci-öğretmen ilişkilerinin olumlu yönde gelişmesine katkı sağlayabilir. Okul yöneticileri mesleki işbirliğgi 
sağlamak için gerekli liderlik rollerini yerine getirmeleri önerilebilir. Okul yöneticilerinin kişisel mesleki gelişim etkinliklerinden bir diğeri bilimsel yayın ve makalelerin takibi etkinliği olupçeşitli araştırma bulgularıyla bu araştırmanın bulguları benzerlik göstermektedir (Can ve Köse, 2015; Gürkan ve Toprakçı, 2018; Polat ve diğerleri, 2018; Özus, 2005).

Okul yöneticilerinin ihtiyaç duydukları mesleki gelişim alanları en fazla oranda okul (iş) sağlığı ve güvenliği, etkili iletişim becerileri, fark yaratan okul ve eğitim yönetimi uygulamaları, eğitimde bilgi teknolojileri kullanma becerisi ve öğrenci disiplin ve davranış sorunları konularında olduğu belirlenmiştir. Okul yöneticilerinin sınıf yönetimi, dokuman yönetim sistemi, protokol kuralları, materyal geliştirme ve uygulama, değerler eğitiminde uygulama teknikleri ve öğrenci değerlendirme uygulamaları konularında mesleki gelişime ihtiyaçları daha az orandadır. Alanyazın incelendiğinde okul yöneticilerinin etkili iletişim becerileri (Aydın, 2015; Baloğlu, 2007; Can ve Köse, 2015; Peretomode ve Dinzei, 2019; Şanlı, 2016), eğitim ve okul yönetimini geliştirici uygulamalar (Can ve Köse, 2015; Polat ve diğerleri, 2018; Şanll, 2016), finans ve bütçe yönetimi (Şanlı, 2016), mevzuat bilgisi (Can ve Köse, 2015; Polat ve diğerleri, 2018; Şanl1, 2016), nezaket kuralları (Can ve Köse, 2015) ve müfredat bilgisi (Can ve Köse, 2015; Nasreen ve Odhiambo, 2018; Şanl1, 2016) konularında mesleki gelişime ihtiyaç duyduklarını belirten araştırma bulguları, bu araştırmanın bulguları destekler niteliktedir. Ayrıca, okul yöneticilerinin bilgi teknolojilerini kullanma becerileri konusunda mesleki gelişim etkinliklerinin önemi birçok araştırmada da ifade edilmiştir (Akkaya, 2010; Baloğlu, 2007; Can ve Köse, 2015; Görgülü, Küçükali ve Ada, 2013; Gürkan ve Toprakçı, 2018; Hacıfazlığlu, Karadeniz ve Dalgıç, 2011; Nasreen ve Odhiambo, 2018; Peretomode ve Dinzei, 2019; Polat ve diğerleri, 2018; Şanl, 2016). Lavigne, Shakman, Zweig ve Greller (2016) okul yöneticilerinin, öğrenci disiplin sorunları gibi okullarda meydana gelebilecek kriz ve özel durumları yönettiklerini belirtmişlerdir. Dolayısıyla, okul yöneticilerine yönelik öğrenci disiplin ve davranış sorunları ile okul (iş) sağlı̆̆ı ve güvenliği konularında mesleki gelişim etkinlikleri önemlidir. Öğrenci değerlendirme uygulamaları konusunda ise Metin (2010), okul yöneticilerinin öğrencilerin durumlarıla ilgili istatistikler tutma ve bunları analiz etme ve yorumlamaya yönelik mesleki gelişim ihtiyaçlarının olduğuna değinmiştir. Tüm bu bulgular doğrultusunda, okul yöneticilerinin ihtiyaçlarına cevap verecek ve ilgili sorunlarını ortadan kaldırmaya yönelik mesleki gelişim etkinlikleri uygulanması ile daha etkili eğitim programları gerçekleşebilir.

Mesleki gelişim etkinliğine katılmak isteyen ve istemeyen okul yöneticilerinin oranları birbirine yakındır. Araştırmanın bu bulgusu, okul yöneticilerinin kendi istekleriyle mesleki gelişim etkinliklerine katıldıklarını belirten Gürkan ve Toprakçı'nın (2018)araştırma bulgularıyla benzerlik göstermektedir. Okul yöneticilerinin mesleki gelişim etkinliklerine katılmama nedenleri arasında uygun mesleki gelişim etkinliğinin olmaması en sık ifade edilen görüştür. Bunu sırasıyla ailevi sorumluluklar ve mesleki gelişim etkinliklerin ücretlerini karşılayamama izlemektedir. Uçar ve İpek (2006) araştırmalarında okul yöneticileri ve öğretmenlerin hizmetiçi eğitim uygulamalarının gerekliliğini vurgulasalar da, hizmet içi eğitim uygulamalarına katılma istekliliğini okul yöneticileri "oldukça" düzeyinde belirtmişlerdir. Baz'ın (2010) araştırmasında, "Hizmetiçi eğitim programlarının ihtiyaç analizleri iyi yapılmadan programlandığını düşünüyorum." ifadesine katılma oranı ön plandadır. Matherson ve Windle (2017) mesleki gelişim etkinliklerine katılımın "otur ve git" şeklinde bir uygulandığını; ancak beklentilerin daha çok yeni bilgi öğrenmek ve uygulamak üzerine olduğuna değinmişlerdir. Erdem ve Şimşek (2013), araştırmalarında okul yöneticilerine sunulan hizmet içi eğitimlerin \% 49'unun teknik, \% 32'sinin insancıl ve \% 19'unun kavramsal yeterliğe yönelik olduğunu belirtmişlerdir. İnsancıl ve kavramsal yeterliklerin geliştirilmesine yönelik hizmet içi eğitimlerin artırılması gerektiğini vurgulamışlardır. Sonuç olarak, bu araştırmayla okul yöneticilerinin mesleki gelişim etkinliklerinden aradıkları beklentiler, ihtiyaç ve amaçlar ile alandaki yenilikleri göz önüne bulundurularak mesleki gelişim etkinliklerinin düzenlenmediğinden bahsedilebilir. Mesleki gelişim etkinliklerinin programları, içeriği, yapısı ve eğitime katılanlar üzerindeki etkisi incelenerek ihtiyaca uygun mesleki gelişim etkinlikleri düzenlenebilir. Okul yöneticilerinin mesleki gelişim etkinliklerine katılma motivasyonlarını düzeyleri artırılabilir.

Okul yöneticilerinin büyük bir çoğunluğu mesleki gelişim etkinliklerine katılmaları için ek ödeme desteğini almamışlardır. Okul yöneticilerinin mesleki gelişimlerine bütçeden yer verilmeme durumu Polat ve diğerleri (2018) ve Baz'ın (2010) araştırmalarında da belirtilmektedir. Baz'ın (2010) araştırmasında da, 
"Ödenek yetersizlikleri nedeniyle hizmet içi eğitim programlarının yeterli sayı ve nitelikte gerçekleştirilmediğini düşünüyorum." ifadeleri ön plandadır. Milli Eğitim Bakanlığı'nın okul yöneticilerine mesleki gelişimleri için bütçe ayırmadıklarını ve maddi destek sağlamadıklarını belirten Daldal (2016) ile Gürkan ve Toprakçı'nın (2018) araştırma bulguları da, bu araştırmanın bulgularını desteklemektedir. Dolayısıyla okul yöneticilerinin mesleki gelişim etkinliklerine katılmaları için maddi teşvikin yapılmaması onların mesleki gelişimlerini olumsuz bir şekilde etkileyebilir. Bu etkiyi azaltabilmek için maddi teşviklerin etkin bir şekilde kullanılması sağlanabilir.

Cinsiyet ve yaş değişkenlerine göre, okul yöneticilerinin mesleki gelişim etkinliklerine katılma sayıları, katılma süreleri ve etkinliklerden etkilenme düzeylerinde anlamlı bir farklılık yokken okul türü değişkenine göre anlamlı bir fark vardır. Araştırmanın bu bulgusu, okul yöneticilerinin cinsiyetlerine göre yansıtıcı düşünme uygulamaları ve becerileri arasında bir ilişki olmadığını belirten Dalgıç'ın (2011) araştırma bulgusuyla benzerlik göstermektedir. İlkokul ve liselerde görev yapan okul yöneticilerine göre mesleki gelişim etkinliklerine katılma sayıları bakımından anlamlı farklılıklar vardır. Buna göre ilkokullarda görev yapan okul yöneticileri liselerde görev yapan okul yöneticilerine göre, mesleki gelişim etkinliklerine katılma sayıları daha fazladır. Bunun nedeni, ilkokul okul yöneticilerinin mesleki gelişim etkinliklerine katılma istekleri ile açıklanabilir. İlkokul okul yöneticilerinin hitap ettiği öğrenci ve öğretmen grubunun farklı olmasından dolayı, öğretmen ve öğrencilerin daha fazla rehberlik ve geliştirmeye yönelik ihtiyaçlarının olduğunu düşündürmektedir. Ayrıca, okul yöneticilerinin mesleki gelişim etkinliklerinden etkilenme ve etkinliklere katılma sürelerinde ise, lise ile ilkokul ve lise ile ortaokullarda görev yapan okul yöneticileri arasında anlamlı farklılıklar vardır. Buna göre liselerde görev yapan okul yöneticileri ilkokul ve ortaokullarda görev yapan okul yöneticilerine göre mesleki gelişim etkinliklerini daha etkili görmekte ve mesleki gelişim etkinliklerine katılma süreleri daha fazladır. Lise okul yöneticilerinin mesleki gelişim etkinliklerine katılım sayıları ilkokul okul yöneticilerine göre her ne kadar daha az olsa da, etkinliklerden etkilenme düzeyleri daha fazladır.

Mesleki gelişim etkinliklerine katılma süresi ile bu etkinliklerin okul yöneticileri üzerindeki etki düzeyleri arasında pozitif yönde ve düşük düzeyde bir ilişki vardır. Bu bulgu okul yöneticilerinin mesleki gelişim etkinliklerine katılma süreleri arttıkça, mesleki gelişimleri üzerindeki etkilerini de artıracağı şeklinde ifade edilebilir. Araştırmada ayrıca, mesleki gelişim etkinliklerine katılma sayısı ile bu etkinliklerden etkilenme düzeyleri arasında negatif yönde ve yüksek düzeyde bir ilişki vardır. Bu bulgu, okul yöneticilerinin mesleki gelişmelerine katılma sıklıkları artıkça etkilenme düzeylerinde azalma meydana geldiğinden bahsedilebilir. Başka bir ifadeyle, okul yöneticilerinin katıldıkları mesleki gelişim etkinlik sayısı artıkça bu etkinliklerden etkilenme düzeyleri azalmaktadır. Özellikle hizmet içi eğitimler bireyin amaç ve ihtiyaçları göz önünde bulundurulmadan gerçekleşirse, eğitim personelinin seviyesine uygun değilse, katılımcllar isteksizse, eğitimi sunan uzmanlar nitelik ve nicelik açısından yetersizse, örgüt yapısından doğan sorunlar varsa, hatalı bir personel politikası uygulanıyorsa ve eğitimler değerlendirilmemişse hizmet içi eğitimlerden beklenen yarar sağlanamaz (Taymaz, 1997). Mesleki gelişim etkinliklerinin birey üzerindeki etkisini artırmak için niceliksel özelliklerden ziyade niteliksel özelliklerine vurgu yapılması önerilebilir.

$\mathrm{Bu}$ araştırma Antalya ili Kemer, Korkuteli ve Serik ilçelerinde yer alan devlet okullarında görev yapan okul yöneticilerinin mesleki gelişim etkinliklerine ilişkin görüşleri ile sınırlı olup; tüm illerde görev yapan okul yöneticilerine genelleme yapılması mümkün değildir. Gelecekte yapılması düşünülen araştırmalarda devlet ve özel okul yöneticilerinin mesleki gelişim etkinliklere yönelik algıları karşılaştırılabilir. Bu araştırmada Türkiye'de okul yöneticilerinin, mesleki ve kişisel gelişimleri gerekli olan için mesleki gelişim etkinliklerin yeteri düzeyde etkili olmadığı ve ihtiyaç duydukları alanda mesleki gelişim etkinliklerine katılamadıklarını göstermektedir. Dolayısıyla, mesleki gelişim etkinliklerinin etkililiği açısından görülen sorunların tespit edilip çözümüne yönelik araştırmaların planlanması gerçekleşebilir. Eğitim sisteminin ve öğretmenlerin geliştirilmesinde önemli bir işleve sahip olan okul yöneticilerinin yetiştirilmesinde ihtiyaçlarını karşılayacak mesleki gelişim etkinliklerine daha fazla yer verilebilir. Mesleki gelişim etkinlik programlarının oluşturulmasında okul yöneticilerinin ihtiyaçları dikkate alınabilir. İhtiyaçları yönelik analiz çalışmaları yapılarak, sayısı ve çeşitlilik artırılabilir. Bununla birlikte, araştırma konusuna ilişkin farklı model ve 
yöntemlerin kullanılmasıyla daha kapsamlı araştırmaların yapılması önerilebilir.

\section{Yazar(lar)ın Beyanı}

Araştırmacıların katkı oran beyanı: Araştırmanın tüm aşamaları yazar tarafından yapılmıştır.

Çatışma beyanı: Araştırmada, yazarın kendi içinde ve diğer kişi/kurum/kuruşlarla herhangi bir çıkar çatışması söz konusu değildir.

Destek ve teşekkür: Bu araştırma, Akdeniz Üniversitesi Bilimsel Araştırma Projeleri Koordinasyon Birimi tarafindan desteklenmiştir. Proje Numarasi: 2017.05.0110.086.

\section{Kaynaklar}

Akkaya, A. E. (2010). Okul yöneticilerinin bilgi teknolojileri becerilerinin ve tutumlarının geliştirilmesi: Bir hizmetçi eğitim uygulaması (Yayınlanmamış yüksek lisans tezi). Akdeniz Üniversitesi, Sosyal Bilimler Enstitüsü, Antalya.

Akın, U. (2012). Okul yöneticilerinin seçimi ve yetiştirilmesi: Türkiye ve seçilmiş ülkelerden farklı uygulamalar, karşılaştırmalar. AİBU Sosyal Bilimler Enstitüsü Dergisi, 12(2) 1- 30.

Aydın, T. (2015). Okul müdürlerinin mentor müdür olarak yetiştirilmesine yönelik deneysel bir çalışma (Yayımlanmamış doktora tezi). Gaziantep Üniversitesi, Eğitim Bilimleri Enstitüsü, Gaziantep.

Aytaç, T. (2000). Hizmetiçi eğitim kavramı ve uygulamada karşılaşılan sorunlar. Milli Eğitim Dergisi, 147, 6669.

Balcı, A., Memduhoğlu, H. B., İlgan, A., Erdem, M. ve Taşdan, M. (2007, Haziran). Bazı Avrupa Birliği ülkeleri ilköğretim okulu yöneticilerinin seçilmesi ve yetiştirilmesi [Öz]. II. Ulusal Eğitim Yönetimi Kongresinde sunulan bildiri, Ankara Üniversitesi, Ankara.

Baloğlu, B. (2007). İlk ve ortaöğretim okulu yönetici yardımcılarının alması gereken hizmetiçi eğitim konuları hakkında okul yöneticilerinin görüşleri. Kırşehir Eğitim Fakültesi Dergisi, 8(1), 167-178.

Balyer, A. ve Gündüz, Y. (2011). Değişik ülkelerde okul müdürlerinin yetiştirilmesi: Türk eğitim sistemi için bir model önerisi. Kuramsal Eğitimbilim Dergisi, 4(2), 182-197.

Baykan, S., Güngen, Y. ve Ünal, S. (1987). Mesleki eğitimde hizmet içi eğitim. Hacettepe Üniversitesi Ĕ̆itim Fakültesi Dergisi, 2, 233-240.

Baz, M. (2010). M.E.B. hizmet içi eğitimlerinin ilköğretim okullarına katkısının ilköğretim öğretmen ve yöneticileri tarafından değerlendirilmesi (Yayımlanmamış yüksek lisans tezi). Yeditepe Üniversitesi, Sosyal Bilimler Enstitüsü, İstanbul.

Bermúdez, J. L. (2003). Thinking without words. Oxford: Oxford University Press.

Budak, Y. ve Demirel, Ö. (2003). Hizmetiçi eğitim ihtiyacı. Kuram ve Uygulamada Eğitim Yönetimi, 9(33), 62-81.

Bursalığlu, Z. (2015). Okul yönetiminde yeni yapı ve davranış (19. baskı). Ankara: PEGEM Akademi Yayınları.

Can, N. ve Köse, A. (2015). İlkokul ve ortaokul yöneticilerinin hizmetiçi eğitim ve geliştirme kavramlarına ilişkin görüşleri ve beklentileri. KSÜ Sosyal Bilimler Dergisi, 12(2), 85-118.

Chen, T. Y., Chang, P. L. ve Yeh, C. W. (2004). An investigation of career development programs, job satisfaction, professional development and productivity: The case of Taiwan. Human Resource Development International, 7(4), 441-463.

Connelly, G. (2008). Leading learning communities, standards for what principals should know and be able to do. Executive summary (2. bask1). Alexandria: National Association of Elementary School Principals.

Cormas, P. C. ve Barufaldi, J. P. (2011). The effective research-based characteristics of professional development of the National Science Foundation's GK-12 program. Journal of Science Teacher Education, 
22(3), 255-272.

Daldal, F. (2016). Kamu kesiminde hizmet içi eğitimin kariyer basamaklarına etkisi: Isparta Milli Eğitim Müdürlüğ̈̈ örneği (Yayınlanmamış yüksek lisans tezi). Süleyman Demirel Üniversitesi, Sosyal Bilimler Enstitüsü, Isparta.

Dalgıç, G. (2011). Okul yöneticilerinin yansıtıcı düşünme beceri ve uygulamalarının incelenmesi: İstanbul ve Kopenhag örneği (Yayımlanmamış doktora tezi). Marmara Üniversitesi, Eğitim Bilimleri Enstitüsü, İstanbul.

Doğan, O. (2009). Hizmetiçi eğitime katılımın eğitim öğretim sürecine etkisi ile ilgili yönetici ve öğretmen görüşleri. (Yayımlanmamış yüksek lisans tezi). Maltepe Üniversitesi, Sosyal Bilimler Enstitüsü, İstanbul.

Edge, K. ve Mylopoulos, M. (2008). Creating cross-school connections: LC networking in support of leadership and instructional development. School Leadership and Management, 28(2), 147-158.

Erakkuş, Ö. (2004). Eğitim kurumlarında yönetici ve öğretmenlerin kişisel gelişim düzeylerindeki artışın öğrenci verimliliğine etkisi ve bir uygulama (Yayımlanmamış yüksek lisans tezi). Dumlupınar Üniversitesi, Sosyal Bilimler Enstitüsü, Kütahya.

Erdem, A. ve Şimşek, S. (2013). Öğretmenlere ve okul yöneticilerine verilen hizmet içi eğitimlerin irdelenmesi. Uşak Üniversitesi Sosyal Bilimler Dergisi, 6(4),94-108.

Ersoy, Y. (1996). Hizmetiçi eğitim ve yetiştirme kurusunu geliştirme-I: Amaçlar ve matematik öğretmenlerinin görüşleri. Hacettepe Üniversitesi Eğitim Fakültesi Dergisi, 12, 151-160.

Fazio, X. (2009). Teacher development using group discussion and reflection. Reflective Practice, 10(4), 529-541.

Fraenkel, J., Wallen, N. ve Hyun, H.H.(2012). How to design and evaluate research in education (8. bs.). Boston: McGraw Hill.

Fullan, M. ve Steigelbauer, S. (1991). The meaning of educational change. New York: Teacher College Press.

Gordon, S. P. (2004). Professional development for school improvement: Empowering learning communites, Boston: Pearson Education.

Görgülü, D., Küçükali, R. ve Ada, Ş. (2013). Okul yöneticilerinin bilgi teknolojileri ile ilgili eğitimleri alma ve kullanma durumlarının incelenmesi. Mehmet Akif Ersoy Üniversitesi Ĕ̆itim Bilimleri Enstitüsü Dergisi, 2(3), $1-20$.

Guskey, T. R. (2002) Does it make a difference? Evaluating professional development. Educational Leadership, $59(6), 45-51$.

Guskey, T. R. (2003). Analyzing list of the characteristics of effective professional development to promote visionary leadership. NASSP Bulletin, 87 (637), 4-21.

Guskey, T. (2009). Closing the knowledge gap on effective, professional development. Educational Horizontal, 87(4), 224-233.

Gümüş, E. (2019). Investigation of mentorship process and programs for professional development of school principals in the U.S.A.: The Case of Georgia. International Journal of Educational Leadership and Management, 7(1), 2-41. doi: 10.17583/ijelm.2019.3718.

Gürkan, H. ve Toprakçı, E. (2018). İlkokul müdürlerinin mesleki gelişimi. E-Uluslararası Ĕ̆itim Araştırmaları Dergisi, 9(2), 64-81. doi:10.19160/ijer.434582

Hacıfazlığlu, Ö., Karadeniz, Ş. ve Dalgıç, G. (2011). Okul yöneticilerinin teknoloji liderliğine ilişkin algıları: Metafor analizi örneği. Eğitim Bilimleri Araştırmaları Dergisi, 1(1), 97-121.

Harris, B. (1989). In-service education for staff development. Boston: Allny \& Bacon.

Ingvarson L., Meiers M. ve Beavis A. (2005). Factors affecting the impact of professional development programs on teachers' knowledge, practice, student outcomes \& efficacy. Education Policy Analysis 
Archives, 13(10), 1-28.

Kahyaoğlu, R. B. (2019). Mesleki gelişim eğitim seminerlerine ilişkin öğretmen görüşleri (Yayınlanmamış yüksek lisans tezi). Akdeniz Üniversitesi, Eğitim Bilimleri Enstitüsü, Antalya

Karataş, İ. H., Radmard, S., Öksüz Gül, F., Varol, N. ve Dağ, Ş. (2019). Türkiye okul yöneticileri raporu 2019. İstanbul: Öncü Okul Yöneticileri Derneği Yayınları.

Kasar, J.ve Clark, E. N. (2000). Developing professional behaviors. Thorofare, NJ: SLACK Inc.

Kayıkçı, K., Altun, M. ve Altun, S. U. (2018). Maarif müfettişlerinin katıldıkları hizmet içi eğitim faaliyetlerinin etkililiğine ilişkin görüşleri. Kuram ve Uygulamada Egitim Yönetimi Dergisi, 24(4), 641-688.

Kızılkaya, H.A. (2012). Öğretmenlerin mesleki gelişimlerinin mesleki gelişime yönelik tutumları ve iş doyumları bakımından incelenmesi üzerine bir araştırma (Yayınlanmamış yüksek lisans tezi). Kırıkkale Üniversitesi, Sosyal Bilimler Enstitüsü, Kırıkkale.

Kocatürk, H. E. (2016). School culture as predictor of teachers' attitudes towards professional development: Mediating role of organizational trust (Yayınlanmamış yüksek lisans tezi). Orta Doğu Teknik Üniversitesi, Sosyal Bilimler Enstitüsü, Ankara.

Lashway, L. (2003). Inducting school leaders. ERIC Digest 170. Erişim adresi: http://eric.uoregon.edu/publications/digests/digest170.html

Lavigne, H. J., Shakman, K., Zweig, J. ve Greller, S. L. (2016). Principals' time, tasks, and professional development: An analysis of Schools and Staffing Survey data (REL 2017-201). Washington, DC: Regional Assistance, Regional Educational Laboratory Northeast \& Islands.

Matherson, L.ve Windle, T. M. (2017). What do teachers want from their professional development? Four emerging themes. Delta Kappa Gamma Bulletin: International Journal for Professional Educators, 83(3), 28-32.

Metin, Y. (2010). İlköğretim okulu öğretmenlerinin yapılandırmacı program ile ilgili hizmetiçi ĕ̆itim ihtiyaçlarımın belirlenmesi (Yayımlanmamış yüksek lisans tezi). Ankara Üniversitesi, Eğitim Bilimleri Ensititüsü, Ankara.

Milli Eğitim Bakanlığı (2006). Milli Eğitim Bakanlığı Hizmetiçi Eğitim Faaliyetlerinin Değerlendirilmesi. Erişim adresi: http://www.meb.gov.tr/earged/earged/Hie_degerlendirme.pdf

Milli Eğitim Bakanlığı (2010). TALIS 2008 uluslararası öğretme ve öğrenme araştırması. Ankara: Gürler Matbaacilık.

Milli Eğitim Bakanlığı (2019a). MEB Öğretmen Yetiştirme ve Geliştirme Genel Müdürlüğü Mesleki Gelişimi Destekleme ve İzleme Dairesi Başkanlığı. Erişim adresi: http://oygm.meb.gov.tr/www/mesleki-gelisimtanitim/icerik/7

Milli Eğitim Bakanlığı (2019b). Personel Genel Müdürlüğü Eğitim Daire Başkanlığı Teşkilat yapısı. Erişim adresi: http://personel.meb.gov.tr/www/icerik_goruntule.php?KNO=230

Murphy, G. A. ve Calway, B. A. (2008). Professional development for professionals: Beyond sufficiency learning. AustralianJournal of Adult Learning, 48(3), 424-444.

Nasreen, A. ve Odhiambo, G. (2018). The continuous professional development of school principals: Current practices in Pakistan. Bulletin of Education and Research, 40(1), 245-266.

Özus, E. (2005). M.E.B. bağlı Konya ilindeki mesleki ve teknik orta öğretim kurumlarında çalışan yönetici ve öğretmenlerin öğrenen organizasyonu algılamaları (Yayınlanmamış yüksek lisans tezi). Selçuk Üniversitesi, Sosyal Bilimleri Enstitüsü, Konya.

Pakkan, G. (1995). Teacher development: An important issue. Hacettepe Üniversitesi Ĕ̆itim Fakültesi Dergisi, 11, 75-78.

Peretomode, V. F. ve Dinzei, M. M. (2019). Professional development needs of public and private secondary 
school principals in Delta State, Nigeria. International Journal of Educational Administration, 11(1), 7-21.

Polat, S., Uğurlu, C. T. ve Aksu, M. B. (2018). Okul yöneticilerinin kendi mesleki gelişimleri ve okulu geliştirmeye yönelik liderlik davranışlarına ilişkin görüşleri. Eğitimde Nitel Araştırmalar Dergisi, 6(1), 205224.

Pürçek, K.I. (2015). Ankara ili devlet ilköğretim okul müdürlerinin koçluk davranışı ve öğretmenlerin iş doyumu düzeyleri ile ilişkisi (Yayımlanmamış doktora tezi). Ankara Üniversitesi, Eğitim Bilimleri Ensititüsü, Ankara.

Rosenholtz, S. J. (1985). Political myth about education reform: Lessons from research on teaching. Phi Delta Kappan, 66(5), 349-355.

Seferoğlu, S. S. (2004). Öğretmen yeterlilikleri ve mesleki gelişim. Bilim ve Aklın Aydınlığında Eğitim Dergisi, 58, 40-45.

Sezgin-Nartgün, Ş. (2006). İlköğretim okulu öğretmenlerinin hizmetiçi eğitim programlarının etkileri üzerine düşünceleri (Bolu İli Örneği). Abant İzzet Baysal Üniversitesi Eğitim Fakültesi Dergisi, 6(1), 157-178.

Sezgin, F., Koşar, S. ve Er, E. (2014). Okul yöneticisi ve öğretmen yetiştirmede mentörlük sürecinin incelenmesi. Kastamonu Ĕ̆itim Dergisi, 22(3), 1337-1356.

Sinha, S. ve Hanuscin, D. L. (2017). Development of teacher leadership identity: A multiple case study. Teaching and Teacher Education, 63, 356-371.

Şahin, M. (1999). Milli Eğitim Bakanlığı hizmetiçi eğitim faaliyetlerinin geliştirilmesine yönelik öneriler. Kuram ve Uygulamada Ĕ̈itim Yönetimi, 5(2), 221-227.

Şanlı, E. (2016). Okul yöneticilerinin uzaktan mesleki gelişimleri: Bir model önerisi (Yayımlanmamış yüksek lisans tezi). İstanbul Üniversitesi, Eğitim Bilimleri Enstitüsü, İstanbul.

Taymaz, A. H. (1997). Hizmetiçi eğitim. Ankara: TAKAV.

Türk Dil Kurumu(2019). Hizmetiçi eğitim. Erişim adresi: https://sozluk.gov.tr/

Uçar, R. ve İpek, C. (2006). İlköğretim okullarında görev yapan yönetici ve öğretmenlerin MEB hizmet içi eğitim uygulamalarına ilişkin görüşleri. Yüzüncü Yıl Üniversitesi Eğitim Fakültesi Dergisi, 3(1), 34-53.

Urlunç, O. (2007). Okul yöneticilerinin hizmetiçi eğitim programlarının değerlendirmesine ilişkin görüşleri (Yayımlanmamış yüksek lisans tezi). Kafkas Üniversitesi, Sosyal Bilimler Enstitüsü, Kars.

Watts, G. E. ve Hammons, J. O. (2002). Professional development: Setting the context. G.E. Watts (Ed.), Enhancing community colleges through professional development (s.5-10) içinde. New Directions for Community Colleges, no.120. San Francisco: Jossey-Bass.

Yılmaz, H. Y. ve Esen, D. G. (2015). An investigation on in-service trainings of the Ministry of National Education (MONE). Procedia-Social and Behavioral Sciences, 186, 79-86. 


\section{EXTENDED ABSTRACT}

\section{Introduction}

Professional development is the combination of formal and informal lifelong learning that covers the period from individuals' pre-service to retirement (Fullan and Steigelbauer, 1991; Kasar and Clark, 2000) and the practices with which they stay up-to-date in technical, legal, conceptual and social change areas required by their professions (Murphy and Calway, 2008). In order to ensure that educational institutions adapt to scientific, technological, economic and social changes, it is necessary to train the education staff in service and to ensure their continuing development (Ingvarson, Meiers and Beavis, 2005; Seferoğlu, 2004; Sezgin-Nartgün, 2006; Şahin, 1999; Taymaz, 1997). In this respect, it is important for management to fulfill its functions of inservice training and school administrator development. It is vital for school administrators to benefit from professional development activities so that both school administrators and other education staff can achieve effective personal and professional development in line with school goals. The present study determines the perceptions of school administrators about their professional development activities. In the light of the literature, the following research questions were developed:

1) What types of professional development activities do school administrators participate in; what is their participation rate in professional development activities; what is the impact level of the professional development activities on them; what is the duration of the professional development activities; what types of professional development activities do they personally participate in; what areas of professional development activities do they need; what are their demands to participate in professional development activities, what are the reasons for not attending professional development activities; and what financial support do they receive for professional development activities?

2) Does the duration, number of participants, and impact level for professional development activities differ based on gender, age, and school type?

3) What are the relationships between the number of school administrator participants, the duration of their participation, and the impact level of professional development activities on them?

\section{Method}

The participants of the general survey study included 100 school administrators selected through a random sampling method and on a volunteer basis. The participants worked in the state primary, secondary, and high schools in the province of Antalya and participated in the "School Administration Seminar". The sample included 18 females and 82 males. Out of the total number of participants, 47 worked in primary schools; 44 worked in secondary schools; and 9 worked in high schools as school administrators. In terms of age, the sample distribution is as follows: 35 years and below $(n=11), 36-40$ years old $(n=13), 41-45$ years old $(n=20), 46-50$ years old $(n=17)$, and 51 years and above $(n=16)$. The research data were collected via the Professional Development Activities Questionnaire. The "Professional Development Activities" survey was designed using the information in these categories: i) personal data; and ii) professional development in TALIS (2008) International Teaching and Learning Survey (MEB, 2010).

\section{Results}

The study findings indicated that among official professional development activities, most school administrators participated in activities like courses and workshops $(f=65)$. The participation rates for school administrators in two of the professional development activities, "study visits to other schools" (55\%) and "educational conferences or seminars" (52\%), was also high. A total of $87 \%(\mathrm{f}=38)$ of school administrators who spent time on study visits to schools and $77 \% \quad(f=40)$ who devoted time to educational conferences/seminars believed that these activities were not very effective. The least-attended professional development activities by school administrators were "diploma/certificate programs" by $20 \%$. The proportion of time school administrators devoted to professional development activities as part of their duties was approximately $68 \%$. A total of $84 \%$ of the school administrators stated that they exchanged ideas with their colleagues on professional issues and $78 \%$ of them stated that they read professional publications and watched 
professional programs. School (occupational) health and safety (20.2\%), effective communication skills $(14,5 \%)$, ability to use information technologies in education $(13 \%)$ and student discipline and behavior problems $(12 \%)$ were among the professional development areas that school administrators needed most. The professional development subjects school administrators needed least included classroom management $(\mathrm{f}=$ $2)$, document management system $(f=2)$, protocol rules $(f=2)$, material development and use $(f=2)$, application techniques in values education $(\mathrm{f}=2)$ and student assessment practices $(\mathrm{f}=1)$. The rate of school administrators who did not want to participate in professional development activities $(f=48)$ and stated that there was no additional payment for the professional development activities they participated in was high $(82 \%)$. Most of the school administrators agreed that "there is no appropriate professional development activity" ( $f=40)$. This was followed by "there is no time due to family responsibilities." $(18,6 \%)$ and "Professional development activities are too expensive/not affordable." $(13,6 \%)$. While there was no statistically significant difference in the number, duration and perceived impact levels of the professional development activities that school administrators participated in based on the variables of gender and age, significant differences were revealed according to school type. A low, positive relationship $(r=0,233, p<0,05)$ was found between the impact levels of the professional activities on school administrators and the duration of the professional development activities in which they participated. There was also a high, negative relationship $(\mathrm{r}=-0,779, \mathrm{p}<0,05)$ between the impact levels of the professional activities on school administrators and the number of participants in professional development activities.

\section{Conclusion}

The impact of professional development activities on school administrators was highest in guiding, observing and training colleagues. Among the unofficial personal professional development activities, school administrators were most affected by the exchange of ideas with colleagues. It was determined that the professional development areas school administrators need most include school (occupational) health and safety, effective communication skills, school and education management practices that make a difference, the ability to use information technology in education, and student discipline and behavior problems. The rate of school administrators who want to participate in professional development activities and the rate of school administrators who do not want to participate in professional development activities are similar. The mostexpressed reason for lack of participation in professional development activities was the lack of appropriate professional development activities. The vast majority of the school administrators did not receive additional payment in support of their participation in professional development activities. While no significant difference was found in the number, duration and perceived impact levels of the professional development activities that school administrators participated in based on the variables of gender and age, a significant difference was observed according to school type. A low and positive relationship was found between the impact levels of the professional activities on school administrators and the duration of the professional development activities in which they participated. Considering this finding, it can be stated that as the duration of the professional development activities that school administrators participate in increases, the impact of these activities on their professional development increases as well. In addition, there is a high and negative relationship between the impact levels of the professional activities on school administrators and the number of participants in professional development activities. In light of this finding, we suggest that as the frequency of school administrators' participation in professional development activities increases, the impact of the activities on them decreases.

This research revealed school administrators' perceptions about the professional development activities in which they participated. This research indicates that Turkey does not provide adequate nor effective professional development activities necessary for the professional and personal development of school administrators. School administrators are not able to attend the professional development activities in the areas they need. With the problems related to the professional development activity effectiveness identified, we now have the research to create a plan to solve them. Professional development activities that meet the need for training school administrators and teachers who perform important functions in the education system development should receive more attention. School administrators' needs should be taken into account while 
developing professional development activity programs. The number and diversity of the programs can be increased by carrying out further needs analyses. In addition, more comprehensive research using different models and methods related to the research subject could be conducted. Future studies should also compare perceptions of state and private school administrators about professional development activities. 